\title{
MEMBRANE PERMEABILITY OF PRUSSIAN CARP (CARASSIUS AURATUS LINNAEUS, 1758) SPERMATOZOA FOR WATER AND CRYOPROTECTANTS MOLECULES
}

\author{
A. Puhovkin, antonpuhovkin@gmail.com, Institute for Problems of Cryobiology and \\ Cryomedicine of the NAS of Ukraine, Kharkiv \\ K. Mikson, kmikson@ukr.net, Institute for Problems of Cryobiology and Cryomedicine \\ of the NAS of Ukraine, Kharkiv
}

Purpose. Determination of permeability parameters of Prussian carp (Carassius auratus Linnaeus, 1758) spermatozoa membranes for water and cryoprotectants molecules as an important stage in the development of a protocol for their cryopreservation by vitrification.

Methodology. Osmotic response of Prussian carp spermatozoa was studied using photoelectric colorimeter KF-77 (Poland) equipped with a magnetic mixer and thermostated cuvette compartment according to our technique. To determine the permeability of plasma membranes of fish spermatozoa to cryoprotectant molecules, they were incubated in the solutions of ethyleneglycol (EG), 1,2propanediol (1,2-PD), methanol (Met) of different concentrations, or a mixture of these cryoprotectants prepared with isotonic $0.12 \mathrm{M} \mathrm{NaCl}$ aqueous solution. Permeability coefficients of spermatozoa plasma membranes for either water $\left(L_{p}\right)$ or cryoprotectant $\left(K_{p}\right)$ molecules were determined by fitting the experimental dependences of relative cell volumes on time and solving theoretical model equations. The activation energy $\left(E_{a}\right)$ of substance transfer through cell membranes was calculated from $\operatorname{In} L_{p}(1 / T)$ or $\operatorname{In} K_{p}(1 / T)$, the slope of which was equal $E_{a} / R$ according to the Arrhenius equation, where $R$ was the universal gas constant.

Findings. It was found that the permeability of Prussian carp spermatozoa membranes to water molecules at $20^{\circ} \mathrm{C}$ was $3,53 \pm 0,18 \times 10^{-14} \mathrm{~m} / \mathrm{N} \cdot \mathrm{s}$, and a decrease in membrane permeability of Prussian carp spermatozoa within the range of $30-18^{\circ} \mathrm{C}$ was characterized by the activation energy of $48 \pm 4 \mathrm{~kJ} / \mathrm{mol}$. A decrease in membrane permeability of Prussian carp spermatozoa for cryopotectants within the range of $30-18^{\circ} \mathrm{C}$ was characterized by the activation energy of $82 \pm 5 \mathrm{~kJ} / \mathrm{mol}$ for ethyleneglycole, $99 \pm 7$ for 1,2-propanediol and $84 \pm 6$ for the mixture. This fact indicates that the molecules of the studied substances penetrate into the spermatozoon via passive diffusion through the lipid bilayer. The data obtained can be used to determine the optimal regime of spermatozoa cryopreservation for cyprinids.

Originality. For the first time, the coefficients of the membranes permeability of Prussian carp spermatozoa to water molecules and cryoprotectants (ethyleneglycol, methanol, 1,2-propanediol) and the activation energy of the these molecules transfer through the membranes were determined.

Practical value. The results of the study are used in the development of media and regimes of cryopreservation of freshwater fish spermatozoa.

Key words: spermatozoa, Prussian carp (Carassius auratus Linnaeus, 1758), membrane permeability, cryoprotectants, activation energy. 


\title{
ПРОНИКНІСТЬ МЕМБРАН СПЕРМАТОЗОЇДІВ КАРАСЯ (CARASSIUS AURATUS LINNAEUS, 1758) ДО МОЛЕКУЛ ВОДИ ТА КРІОПРОТЕКТОРІВ
}

\author{
А. Ю. Пуговкін, antonpuhovkin@gmail.com, Інститут проблем кріобіології і \\ кріомедицини НАН України, м. Харків \\ К. Б. Міксон, kmikson@ukr.net, Інститут проблем кріобіології і кріомедицини НАН \\ України, м. Харків
}

Мета. Визначення параметрів проникності клітинних мембран сперматозоїдів карася Carassius auratus (L., 1758) до молекул води та кріопротекторів як важливий етап розробки протоколу їх кріоконсервування методом вітрифікації.

Методика. Осмотичні реакції сперматозоїдів досліджували за допомогою фотоелектроколориметра KF-77(Польща), обладнаного магнітним перемішувачем $i$ термостатованим кюветним відділенням за розробленою нами методикою. Для визначення коефічієнта проникності плазматичних мембран сперматозоїдів до молекул кріопротекторів сперматозоїди інкубували в розчинах етиленгліколю, 1,2-пропандіолу, метанолу різних концентрацій або суміші вказаних кріопротекторів, виготовлених на ізотонічному до спермальної плазми 0,12 М водному розчині $\mathrm{NaCl}$. Коефіiцієнт проникності плазматичних мембран сперматозоїдів для молекул води $\left(L_{p}\right)$ та кріопротекторів $\left(K_{p}\right)$ визначали, апроксимуючи експериментальні залежності відносних об'ємів клітин від часу з рішеннями рівнянь теоретичної моделі. Енергію активації $\left(E_{a}\right)$ прочесу перенесення речовин через мембрани клітин розраховували із залежностей $\ln L_{p}(1 / T)$ або $\ln K_{p}(1 / T)$, нахил яких згідно з рівнянням Ареніуса дорівнює $E_{a} / R$, де $R-$-універсальна газова постійна.

Результати. Встановлено, що за температури $20^{\circ} \mathrm{C}$ коефріцієнт проникності мембран сперматозоїдів карася до молекул води становить $3,53 \pm 0,18 \times 10^{-14} \mathrm{~m}^{3} / \mathrm{H} \cdot \mathrm{c}$, а його зниження в діапазоні температур $30-18^{\circ} \mathrm{C}$ характеризується енергією активації $48 \pm 4$ кДж/моль. Зниження коефіцієнтів проникності мембран до молекул кріопротекторів в діапазоні температур $30-18^{\circ} \mathrm{C}$ характеризується енергією активації $82 \pm 5$ кДж/моль для

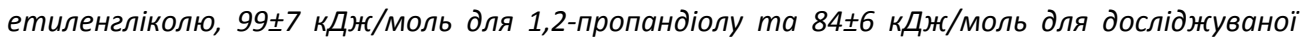
суміші кріопротекторів. Цей фокт свідчить про те, що молекули досліджених речовин проникають у сперматозоїд шляхом пасивної дифузії через ліпідний бішар. Отримані дані можуть бути використані для визначення оптимального режиму кріоконсервування сперматозоїдів коропових риб.

Наукова новизна. Вперше визначені коефіцієнти проникності мембран сперматозоїдів карася до молекул води та кріопротекторів етиленгліколю, метанолу, 1,2-пропандіолу та енергії активації переносу молекул цих речовин через мембрани.

Практична значимість. Результати роботи використовуються при розробчі середовищ і режимів кріоконсервування сперматозоїдів прісноводних риб.

Ключові слова: сперматозоїди, карась Carassius auratus (L., 1758) проникність мембран, кріопротектори, енергія активації.

\section{ПРОНИЦАЕМОСТЬ МЕМБРАН СПЕРМАТОЗОИДОВ КАРАСЯ (CARASSIUS AURATUS LINNAEUS, 1758) ДЛЯ МОЛЕКУЛ ВОДЫ И КРИОПРОТЕКТОРОВ}

А. Ю. Пуговкин, antonpuhovkin@gmail.com, Институт проблем криобиологии и криомедицины НАН Украины, г. Харьков

К. Б. Миксон, kmikson@ukr.net, Институт проблем криобиологии и криомедицины НАН Украины, г. Харьков 
Цель. Определение параметров проницаемости клеточных мембран сперматозоидов карася Carassius auratus (L., 1758) для молекул воды и криопротекторов как важный этап разработки протокола их криоконсервирования методом витрификации.

Методика. Осмотические реакции сперматозоидов исследовали с помощью фотоэлектроколориметра KF-77 (Польша), оборудованного магнитной мешалкой и термостатированным кюветным отделением по разработанной нами методике. Для определения коэффициента проницаемости плазматических мембран сперматозоидов для молекул криопротекторов сперматозоиды инкубировали в растворах этиленгликоля, 1,2пропандиола, метанола различных концентраций или смеси указанных криопротекторов, изготовленных на изотоническом к спермальной плазме 0,12 M водном растворе $\mathrm{NaCl}$. Коэффициент проницаемости плазматических мембран сперматозоидов для молекул воды $\left(L_{p}\right)$ и криопротекторов $\left(K_{p}\right)$ определяли, аппроксимируя экспериментальные зависимости относительных объемов клеток от времени с решениями уравнений теоретической модели. Энергию активации ( $\left.E_{a}\right)$ процесса переноса веществ через мембраны клеток рассчитывали с зависимостей $\ln L_{p}(1 / T)$ или $\ln K_{p}(1 / T)$, наклон которых, согласно уравнению Аррениуса, равен $E_{a} / R$, где $R-$ - универсальная газовая постоянная.

Результаты. Установлено, что при температуре $20^{\circ} \mathrm{C}$ коэффициент проницаемости

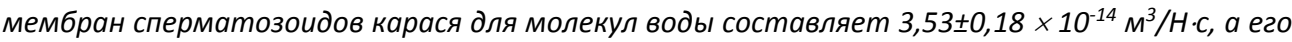
снижение в диапазоне температур $30-18^{\circ} \mathrm{C}$ характеризуется энергией активации $48 \pm 4$ кДж/моль. Снижение коэффициентов проницаемости мембран для молекул криопротекторов в диапазоне температур 30-18 ${ }^{\circ} \mathrm{C}$ характеризуется энергией активации

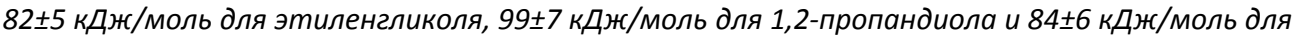
исследуемой смеси криопротекторов. Этот факт свидетельствует о том, что молекуль исследованных веществ проникают в сперматозоид путем пассивной диффузии через липидный бислой. Полученные данные могут быть использованы для определения оптимального режима криоконсервирования сперматозоидов карповых рыб.

Научная новизна. Впервые определены коэффициенты проницаемости мембран сперматозоидов карася для молекул воды и криопротекторов этиленгликоля, метанола, 1,2-пропандиола и энергии активации переноса молекул этих веществ через мембраны.

Практическая значимость. Результаты работы используются при разработке сред и режимов криоконсервирования сперматозоидов пресноводных рыб.

Ключевые слова: сперматозоиды, карась Carassius auratus (L., 1758), проницаемость мембран, криопротекторы, энергия активации.

\section{PROBLEM STATEMENT AND ANALYSIS OF LAST ACHIEVEMENTS AND PUBLICATIONS}

Recently, more and more attention has been paid to the problem of preserving the biodiversity of the animal world. One of the ways to solve this problem is to use the genomes cryopreservation technology for rare and endangered species. The protocols for cryopreservation of sperm are characterized by a high species-specificity: in fact, a unique method of their low-temperature storage must be created for each animal species $[1,2]$.

Methods of slow cooling cryopreservation have been developed for sperm of many fish species; however, they are often insufficiently effective, since they do not provide high cell viability after thawing. In addition, due to the high variability of fish sperm quality, the abovementioned cryopreservation method may be ineffective for the sperm of fish from a different population [3]. An alternative to slow cooling cryopreservation is the vitrification method, one of the advantages of which is the cryopreservation procedure simplification [4-7]. Although, the method of cryopreservation method of 
sperm from Prussian carp (Carassius auratus Linnaeus, 1758) continues to be improved [8-11], there are no data about vitrification method for sperm of this fish species.

Also, it should be noted that the methods of sperm thawing are improved mainly empirically, that is, by selecting the composition of cryoprotective media and thawing modes. Accordingly, a theoretically grounded approach to cryopreservation of spermatozoa is almost not developed today. Rendering to this approach, it is necessary to determine the reasons for intra- and interspecies differences in cryoresistance of spermatozoa and properties associated with its resistance to cryopreservation factors. This situation has arisen due to the incompleteness of information on the characteristics of fish spermatozoa resistance to the factors of cryopreservation.

Note, that keeping spermatozoa in hypertonic solutions of cryoprotectants, even without freezing, can cause significant fluctuations in cell volume [12]. This, in turn, can damage spermatozoa or effect on their sensitivity to cryopreservation factors. Also, a significant problem in the development of vitrification methods is the need to expose cells in high concentration cryoprotectant solutions.

Thus, the study of the osmotic sensitivity of fish spermatozoa and its changes under the influence of cryopreservation factors is relevant. Actually, the permeability of plasma membranes to water molecules and cryoprotectants is an important parameter for determining the cooling rates in the process of fish genetic material cryopreservation - sperm, first of all [13].

\section{HIGHLIGHT OF THE EARLIER UNRESOLVED PARTS OF THE GENERAL PROBLEM. AIM OF THE STUDY}

To select the modes and media for cryopreservation, it is necessary to take into account the parameters of spermatozoa, which characterize osmotic resistance - the property of cells to maintain viability as a result of changes in the osmotic pressure of the external environment.

To date, only a few studies results of fish spermatozoa membranes permeability to water and cryoprotectants are known [14-19]. This can be explained both by the species specificity of fish spermatozoa and by the lack of convenient methods that would make it possible to determine the osmotic characteristics of spermatozoa immediately before cryopreservation and to conduct experiments in the field [20].

The aim of this work is to determine the permeability parameters of the Prussian carp (Carassius auratus Linnaeus, 1758) spermatozoa cell membranes to water and cryoprotectants molecules as an important stage in the development of a protocol for their cryopreservation by vitrification method.

\section{MATERIALS AND METHODS}

In our research, the spermatozoa of Prussian carp (Carassius auratus Linnaeus, 1758) was examined. Experiments on animals were carried out in accordance with the "General Principles of Experiments on Animals" (Kyiv, 2001) and the "European Convention for the Protection of Vertebrate Animals used for Experimental and Other Scientific Purposes" (Strasbourg, 1986).

The experiment was carried out on 12 males aged 20 months, the average weight of which was 170-200 g. Before obtaining sperm, abovementioned males were kept at a 
temperature of $20-22^{\circ} \mathrm{C}$ in fish breeding pools, for at least 7 days. Sperm was obtained using the pituitary injections method accepted in fish farming practice at the rate of 1 $\mathrm{mg} / \mathrm{kg}$ body weight once. The sperm was collected in dry and clean containers by expression.

The osmolarity of the activating solutions and sperm plasma was determined using an automatic cryoscopic osmometer OSMOMAT 030 (Gonotec Gmbh, Germany).

Osmotic reactions of spermatozoa were studied using a KF-77 colour density (Poland) equipped with a magnetic stirring device and a thermostat cuvette compartment in accordance with our methodology [21].

To determine the permeability coefficient of the spermatozoa plasma membranes to cryoprotectant molecules, they were incubated in solutions of ethylene glycol, 1,2propanediol, methanol of various concentrations, or a mixture of these cryoprotectants made on $0.12 \mathrm{M}$ aqueous $\mathrm{NaCl}$ solution (isotonic to the plasma of sperm).

The coefficient of spermatozoa plasma membranes permeability for water molecules $(\mathrm{Lp})$ and cryoprotectants $(\mathrm{Kp})$ was determined by approximating the experimental relationships and relative cell volumes with time and solutions of the equations of the theoretical model [22]. The activation energy (Ea) of the substances transfer through the cell membranes was calculated from the $\operatorname{lnLp}(1 / \mathrm{T})$ dependences, the slope of which, according to the Arrhenius equation, is equal to Ea / R, where $\mathrm{R}$ is the universal gas constant.

The results were statistically processed using next software: Origin 8.5 (OriginLab Corporation, USA) and Microsoft Office Excel (USA). Data are presented as mean \pm standard deviation. Differences were considered statistically significant at $p<0.05$.

\section{STUDY RESULTS AND THEIR DISCUSSION}

A characteristic feature of fish spermatozoa is that a change in the osmolarity of the extracellular environment is quite natural for them. So, during spawning, sperm are released into the water, which leads to the activation of their movement and, as a result, the ability to fertilize eggs. Therefore, unlike many other cells of the organism, for which hypoosmotic tests are mainly purely artificial, and osmotic shock is an extreme factor, incubation of fish spermatozoa under hypoosmotic conditions allows the study of a specific osmotic reaction, which can be of important functional importance (for example, attracting it to the mechanisms of activating the movement of spermatozoa, limiting the time of motility, etc.).

From the point of cryobiology view, the osmotic reaction of a cell can be associated with its cryoresistance, since the transmembrane movement of water is one of the main processes that affect the resistance of cells to cryopreservation factors. However, the data available in the literature are not yet sufficient to analyze the correlation of fish spermatozoa osmotic response with their cryoresistance. At the same time, there is a tendency to the fact that a greater permeability of membranes to water is characteristic of cells more resistant to cryopreservation factors.

Cryopreservation of fish spermatozoa, as a rule, involves the use of a multicomponent composition of a cryoprotective medium. Considering the speciesspecificity of spermatozoa, in order to achieve their high viability after thawing, for cryopreservation each fish species must have its own composition of the cryoprotective 
medium. In cases where different cryoprotective media are used for different fish species, comparison of the spermatozoa cryostability can be subjective and speculative.

On the other hand, the optimization of the technology for cryopreservation of sperm is aimed at increasing the survival of cells after thawing, including by modifying the composition of the cryoprotective medium. An alternative to the empirical approach is a theoretically substantiated approach to spermatozoa cryopreservation, which consists in determining the causes of intra- and interspecies differences in cryoresistance of spermatozoa and properties associated with their resistance to cryopreservation factors. At the same time, the modification of cryoprotective environment composition is based on the output morphological and functional characteristics of spermatozoa [23].

Among such characteristics in our research we singled out the osmotic reaction of cells.

An important indicator is the rate of cryoprotectant penetration at the stage of equilibration with it to freezing. The use of the modified physical and mathematical model of Kedem - Kachalsky makes it possible to calculate the coefficient of permeability of spermatozoa membranes. If the kinetics of the relative cell volume is known, then the morphometric characteristics of cells must be taken into account to calculate the permeability parameter. Assuming the shape of the spermatozoon head is spherical and assuming an average radius of $1.6 \mu \mathrm{m}$, the surface-volume ratio $\gamma$ of the cell is $1.88 \mu^{-1}$ [24]. The permeability of Prussian carp spermatozoa membranes to water molecules calculated according to this model for $20{ }^{\circ} \mathrm{C}$ is $3.53 \pm 0.18 \times 10^{-14} \mathrm{~m}^{3} /$ $\mathrm{N} \times \mathrm{s}$.

As you know, the membrane permeability coefficient depends on the temperature of the medium. By varying the temperature of the incubation medium of spermatozoa at a fixed osmolarity, we obtained the temperature dependence of the membranes permeability of crucian carp spermatozoa for water molecules.

An array of data on the coefficients of permeability of sperm membranes for each of the studied cryoprotectants in the temperature range of $30-18{ }^{\circ} \mathrm{C}$ was depicted as points in the Arenius coordinates $[\operatorname{lnK}=\mathrm{F}(1 / \mathrm{T})]$.

A decrease in membrane permeability coefficients in the temperature range of 30$18^{\circ} \mathrm{C}$ is characterized by an activation energy of $48 \pm 4 \mathrm{~kJ} /$ mol (Fig. 1).

The activation energy for the transfer of water molecules across the cell membrane is an energy barrier that water molecules overcome during the reaction. The activation energy value of $48 \pm 4 \mathrm{~kJ} / \mathrm{mol}$ indicates the mechanism of water molecules transfer by passive diffusion through the lipid bilayer.

At the second stage of the work, we determined the penetration rates of some cryoprotectants through the membranes of Prussian carp spermatozoa. Since cryoprotectants in a relatively high concentration must be used for cryopreservation by vitrification, one of the options for reducing their toxic effect is to use a mixture. We investigated the processes of equilibration of Prussian carp spermatozoa with methanol (final concentration 5\%), ethylene glycol (final concentration 10\%), 1,2-propanediol (final concentration $20 \%$ ), as well as their mixture in the above concentrations. 


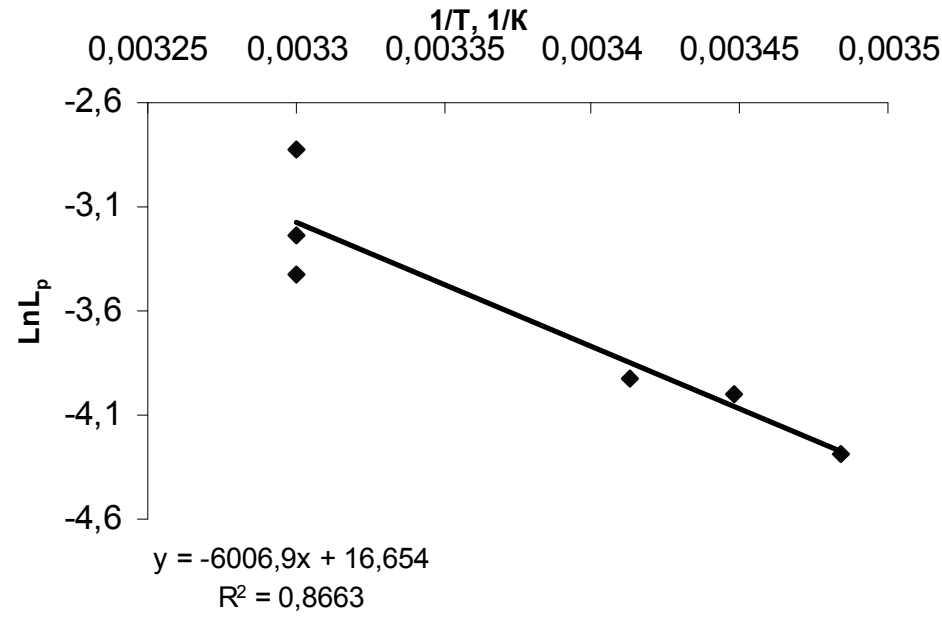

Fig. 1. A typical Arhenius curve for calculating the activation energy of the water molecules transfer through the crucian carp spermatozoa membranes.

In fig. 2 shows the unit-normalized kinetic dependences of the penetration of substances into spermatozoa.

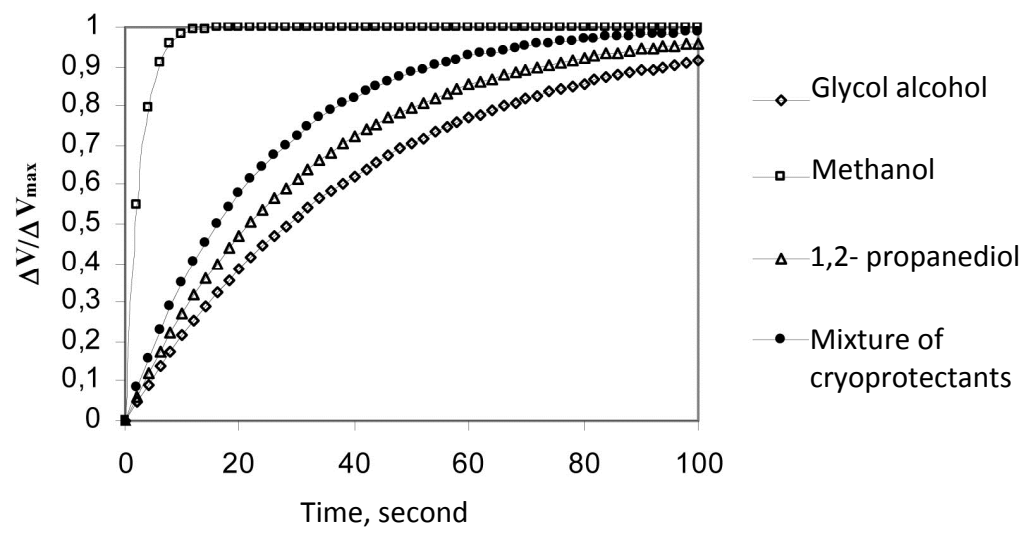

Fig. 2. Kinetic curves of crucian carp spermatozoa equilibrium with cryoprotectant solutions.

Methanol has the highest rate of penetration into cells. Molecules of 1,2propanediol and ethylene glycol are characterized by significantly lower rates. The mixture of the aforementioned cryoprotectants is expected to have an average penetration rate. At the same time, a decrease in the coefficients of membrane permeability to cryoprotectant molecules in the temperature range of $30-18{ }^{\circ} \mathrm{C}$ is characterized by the activation energy $82 \pm 5 \mathrm{~kJ} /$ mol for ethylene glycol, $99 \pm 7 \mathrm{~kJ} /$ mol for 1,2-propanediol, and $84 \pm 6 \mathrm{~kJ} / \mathrm{mol}$ for the test mixture of cryoprotectants. Note, that in connection with a high rate of methanol penetration through cell membranes, measurements of the activation energy of this process have a significant error, therefore, these results are not presented. 


\section{CONCLUSION AND PERSPECTIVES OF FURTHER DEVELOPMENT}

Thus, in this work, for the first time, the coefficients of permeability of Prussian carp spermatozoa membranes to water molecules and cryoprotectants of ethylene glycol, methanol, 1,2-propanediol and the activation energy of the molecules transfer of these substances through the membranes were determined. The results obtained regarding the biophysical characteristics of the Prussian carp (Carassius auratus, Linnaeus 1758) spermatozoa membranes can be used to substantiate the composition of cryoprotective media for cryopreservation by vitrification method.

\section{LITERATURE}

1. Cryopreservation of fish sperm: applications and perspectives / E. Cabrita et al. // J. Appl. Ichthyol. 2010. Vol. 26. P. 623-635.

2. Kopeika E., Kopeika J., Zhang T. Cryopreservation of fish sperm // Cryopreservation and freeze-drying protocols / ed. Day J. G., Stacey G. N. Totowa, New Jersey : Humana Press, 2007. P. 203-217.

3. Bobe J., Labbé C. Egg and sperm quality in fish // General and Comparative Endocrinology. 2010. Vol. 165. P. 535-548.

4. Progress and challenges of fish sperm vitrification: A mini review / Xin M. et al. // Theriogenology. 2017. Vol. 98. P. 16-22.

5. Development of sperm vitrification protocols for two endangered salmonid species: the Adriatic grayling, Thymallus thymallus, and the marble trout, Salmo marmoratus / Kása E. et al. // Fish Physiology and Biochemistry. 2018. Vol. 44. P. $1499-1507$.

6. Development of sperm vitrification protocols for freshwater fish (Eurasian perch, Perca fluviatilis) and marine fish (European eel, Anguilla anguilla) / Kása E. et al. // General and Comparative Endocrinology. 2017. Vol. 245. P. 102-107.

7. Vitrification as an Alternative Approach for Sperm Cryopreservation in Marine Fishes / Cuevas-Uribe R. et al. // North American journal of aquaculture. 2017. Vol. 79(2). P. 187-196.

8. Kutluyer F., Öğretmen F., İnanan B. E. Cryopreservation of Goldfish (Carassius Auratus) Spermatozoa: Effects of Extender Supplemented with Taurine on Sperm Motility and DNA Damage // CryoLetters. 2016. Vol. 37 (1) P. $41-46$.

9. Kutluyer F., Öğretmen F., İnanan B. E. Effects of Semen Extender Supplemented with Lmethionine and Packaging Methods (Straws and Pellets) on Post-Thaw Goldfish (Carassius Auratus) Sperm Quality and DNA Damage // CryoLetters. 2015. Vol. 36 (5). P. 336-343.

10. Taghizadeh V., Imanpoor M.R., Sadeghi A. Effect of Extenders and Different Concentrations of Methanol on Motility Parameters of Goldfish (Carassius auratus gibelio) Spermatozoa after Short-Term Storage // World Journal of Fish and Marine Sciences. 2013. Vol. 5(5). P. 492-496.

11. A brief exposure to low $\mathrm{pH}$ prior to refrigerated storage reduces the motility and viability of goldsh sperm (Carassius auratus, Linnaeus, 1758) / Chantzaropoulos A. et al. // Journal of Applied Ichthyology. 2015. Vol. 31(S1). P. 89-93.

12. The hypoosmotic swelling test performed with coulter counter: a method to assay functional integrity of sperm membrane in rainbow trout / E. Cabrita et al. // Animal Reproduction Science. 1999. Vol. 55. P. 279-287.

13. Petrunkina A. M. Fundamental aspects of gamete cryobiology // Journal of Reproductive Medicine and Endocrinology. 2007. Vol. 4. P. 78-91. 
14. Subzero water permeability parameters and optimal freezing rates for sperm cells of the southern platyfish, Xiphophorus maculates / Pinisetty D. et al. // Cryobiology. 2005. Vol. 50. P. 250-263.

15. Biophysics of zebrafish (Danio rerio) sperm / Hagedorn M. et al. // Cryobiology. 2009. Vol. 58. P. 12-19.

16. Исследование проницаемости мембран сперматозоидов карпа для молекул воды / Пуговкин А. Ю. и др. // Биофизика. 2014. Т. 59, № 3. С. 481-487.

17. Проникність мембран сперматозоїдів стерляді (Acipenser ruthenus, L., 1758) для молекул води / Пуговкін А. Ю. та ін. // Рибогосподарська наука України. 2016. № 1 (35). С. $70-77$.

18. Дослідження осмотичної чутливості сперматозоїдів щуки (Esox lucius, L., 1758) для оптимізації їх кріоконсервування / Пуговкін А. Ю. та ін. // Рибогосподарська наука України. 2016. № 4. С. 103-112.

19. Puhovkin A. Y., Kopeika E. F. Investigation of water and cryoprotectants molecules transfer through common carp (Cyprinus carpio, L.) spermatozoa membranes (CRYO conference of the Society for Cryobiology, Ostrava, Czech Republic, 2015) // Cryobiology. 2015. Vol. 71, № 3. P. 567.

20. Fauvel C., Suquet M., Cosson J. Evaluation of fish sperm quality // Appl. Ichthyol. 2010. Vol. 26. P. 636-643.

21. Спосіб визначення проникності мембран сперматозоїдів коропа до молекул води : пат. 104809 Україна. № u 201215035; заявл. 27.12.2012; опубл. 11.03.2014, Бюл. № 5 .

22. Пуговкін А. Ю., Копєйка Є. Ф. Проникність плазматичних мембран сперматозоїдів коропа (Cyprinus carpio, L., 1758) для молекул води та кріопротекторів на різних етапах кріоконсервування // Проблемы криобиологии и криомедицины. 2016. Т. 26, № 4. С. 340-348.

23. Оптимізація умов кріоконсервування сперми стерляді (Acipenser ruthenus, L. 1758 ) для запліднення ікри в умовах рибних господарств / Кононенко I. С. та ін. // Рибогосподарська наука України. 2017. № 3(41). С. 83-97.

24. Fürböck S., Lahnsteiner F., Patzner R. A. A fine structural review on the spermatozoa of Cyprinidae with attention to their phylogenetic implications // Histol Histopathol. 2009. Vol. 24(10). P. 1233-1244.

\section{REFERENCES}

1. Cabrita, E., Sarasquete, C., Martínez-Páramo, S., Robles, V., Beirão, J., PérezCerezales, S., \& Herráez, M. P. (2010). Cryopreservation of fish sperm: applications and perspectives. J. Appl. Ichthyol., 26, 623-635.

2. Kopeika, E., Kopeika, J., \& Zhang, T. (2007). Cryopreservation of fish sperm. Cryopreservation and freeze-drying protocols. Totowa, New Jersey: Humana Press, 203-217.

3. Bobe, J., \& Labbé, C. (2010). Egg and sperm quality in fish. General and Comparative Endocrinology, 165, 535-548.

4. Xin, M., Siddique, M. A. M., Dzyuba, B., Cuevas-Uribe, R., Shaliutina-Kolešová, A., \& Linhart, O. (2017). Progress and challenges of fish sperm vitrification: A mini review. Theriogenology, 98, 16-22.

5. Kása, E., Lujić, J., Marinović, Z., Kollár, T., Bernáth, G., Bokor, Z., Urbányi, B., Lefler, K.K., Jesenšek, D., \& Horváth, Á. (2018). Development of sperm vitrification protocols for two endangered salmonid species: the Adriatic grayling, 
Thymallus thymallus, and the marble trout, Salmo marmoratus. Fish Physiology and Biochemistry, 44, 1499-1507.

6. Kása, E., Bernáth, G., Kollár, T., Zarski, D., Lujić, J., Marinović, Z., \& Horváth, A. (2017). Development of sperm vitrification protocols for freshwater fish (Eurasian perch, Perca fluviatilis) and marine fish (European eel, Anguilla anguilla). General and Comparative Endocrinology, 245, 102-107.

7. Cuevas-Uribe, R., Hu., E., Daniels, H., Gill, A.O., \& Tiersch, T.R. (2017). Vitrification as an Alternative Approach for Sperm Cryopreservation in Marine Fishes. North American journal of aquaculture, 79(2), 187-196.

8. Kutluyer, F., Öğretmen, F., \& İnanan, B.E. (2016). Cryopreservation of Goldfish (Carassius Auratus) Spermatozoa: Effects of Extender Supplemented with Taurine on Sperm Motility and DNA Damage. CryoLetters, 37(1), 41-46.

9. Kutluyer, F., Öğretmen, F., \& İnanan, B.E. (2015). Effects of Semen Extender Supplemented with Lmethionine and Packaging Methods (Straws and Pellets) on Post-Thaw Goldfish (Carassius Auratus) Sperm Quality and DNA Damage. CryoLetters, 36(5), 336-343.

10. Taghizadeh, V., Imanpoor, M.R., \& Sadeghi, A. (2013). Effect of Extenders and Different Concentrations of Methanol on Motility Parameters of Goldfish (Carassius auratus gibelio) Spermatozoa after Short-Term Storage. World Journal of Fish and Marine Sciences, 5(5), 492-496.

11. Chantzaropoulos, A., Nathanailides, C., Kokokiris, L., Barbouti, A., \& Zhang, T. (2015). A brief exposure to low $\mathrm{pH}$ prior to refrigerated storage reduces the motility and viability of goldsh sperm (Carassius auratus, Linnaeus, 1758). Journal of Applied Ichthyology, 31(S1), 89-93.

12. Cabrita, E., Alvarez, R., Anel, E., \& Herraez, M. P. (1999). The hypoosmotic swelling test performed with coulter counter: a method to assay functional integrity of sperm membrane in rainbow trout. Animal Reproduction Science, 55, 279-287.

13. Petrunkina, A. M. (2007). Fundamental aspects of gamete cryobiology. Journal of Reproductive Medicine and Endocrinology, 4, 78-91.

14. Pinisetty, D., Huang, C., \& Dong, Q., et al. (2005). Subzero water permeability parameters and optimal freezing rates for sperm cells of the southern platyfish, Xiphophorus maculates. Cryobiology, 50, 250-263.

15. Hagedorn, M., Ricker, J., McCarthy, M., et al. (2009). Biophysics of zebrafish (Danio rerio) sperm. Cryobiology, 58, 12-19.

16. Puhovkin, A. Y., Kopeika, E. F., Nardid, O. A., \& Cherkashina, Y. O. (2014). Investigation of membrane permeability of carp spermatozoa for water molecules. Biofizika, 59(3), 481-487.

17. Puhovkin, A. Y., Kononenko, I. S., Cherepnin, V. O., Hrytsyniak, I. I., \& Kopeika, E. F. (2016). Permeability of sterlet sperm membranes (Acipenser ruthenus L., 1758) for water molecules. Fisheries Science of Ukraine, 1, 70-77.

18. Puhovkin, A. Y., Kopeika, E. F., Mikson, K. B., Cherepnin, V. O., \& Hrytsyniak, I. I. (2016). A study of the osmotic sensitivity of pike (Esox lucius, L., 1758) spermatozoa for the optimization of their cryopreservation. Fisheries Science of Ukraine, 4, 103-112.

19. Puhovkin, A. Y., \& Kopeika, E. F. (2015). Investigation of water and cryoprotectants molecules transfer through common carp (Cyprinus carpio, L.) spermatozoa membranes (CRYO conference of the Society for Cryobiology, Ostrava, Czech Republic, 2015). Cryobiology, 71(3), 567. 
20. Fauvel, C., Suquet, M., \& Cosson, J. (2010). Evaluation of fish sperm quality. Appl. Ichthyol, 26, 636-643.

21. Puhovkin, A. Y., Kopeika, E. F., Hordiienko, Y. O., \& Nardid, O. A. (2014). Sposib vyznachennia pronyknosti membran spermatozoidiv koropa do molekul vody. Patent of Ukraine. №104809.

22. Puhovkin, A. Y., \& Kopeika, E. F. (2016). Plasma Membrane Permeability of Carp (Cyprinus carpio, L., 1758) Spermatozoa for Water and Cryoprotectants Molecules at Different Stages of Cryopreservation. Problems of Cryobiology and Cryomedicine, 26(4), 340-348.

23. Kononenko, I. S., Puhovkin, A. Y., Kononenko, R. V. Cherepnin, V. O., Butskyi, K. I., \& Kopeika, E. F. (2017). Optimization of the conditions of starlet (Acipenser ruthenus, L., 1758) sperm cryopreservation for egg fertilization in fish farm conditions. Fisheries Science of Ukraine, 3(41), 83-97.

24. Fürböck, S., Lahnsteiner, F., \& Patzner, R. A. (2009). A fine structural review on the spermatozoa of Cyprinidae with attention to their phylogenetic implications. Histol. Histopathol., 24(10), 1233-1244. 